\title{
EFFECT OF GREEN TEA LEAVES (CAMELLIA SINENSIS) AND CAROM SEEDS (TRACHYSPERMUM AMMI) EXTRACTS ON MALE MICE EXPOSED TO DIAZINON
}

\author{
MANJU OHRI PAI*, VENKATESH S PAI ${ }^{2}$, ANIL K GUPTA ${ }^{3}$
}

${ }^{1}$ Department of Microbiology, All India Institute of Medical Sciences, Rishikesh, India. ${ }^{2}$ Department of Medicine, All India Institute of Medical Sciences, Rishikesh, India. ${ }^{3}$ Department of Medical Microbiology and Medical Lab Technology, Sardar Bhagwan Singh Institute of Biomedical Sciences, Balawala, Dehradun, India. Email: manjupanacea@yahoo.co.in

Received: 04 September 2017, Revised and Accepted: 31 October 2017

ABSTRACT

Objective: The present communication is based on herb, namely, Trachyspermum ammi L. belonging to family Apiaceae, commonly known as "Ajowan" or carom seeds, and green tea (Camellia sinensis, Theaceae) for the prevention of intoxication induced with a sublethal dose of diazinon.

Methods: Male mice weighing around $6.5 \mathrm{mg} / \mathrm{kg}$ body weight were exposed to diazinon, a common pesticide used in plant cultivation. Carom seed and green tea leave extracts were given thereafter to the male mice to check their effect on the toxicity of diazinon.

Results: After several weeks of exposure to these herbal extracts, there was a significant change observed in the hematobiochemical parameters with a significant increase in values of serum alanine aminotransferase, aspartate aminotransferase, gamma-glutamyl transferase, alkaline phosphatase, creatine kinase, creatinine, glucose, and cholesterol. In contrast, no significant statistical difference was perceived in the values of all hematobiochemical parameters in mice treated with tea leaves extract, carom seed extract, and tea leave and carom seed extracts except the value of serum cholesterol in mice treated with carum seed extract which decreased as compared to the control group.

Conclusion: These findings suggest the importance of the carom seeds and green tea and their combinatorial usage against diazinon toxicity, thus promising these plant products to be promising therapeutic agents against hepatotoxicity, cardiotoxicity, nephrotoxicity, and metabolic disorders due to diazinon toxicity. This also makes the safety of herbal products an important public health issue.

Keywords: Carom seeds, Trachyspermum ammi L., Camellia sinensis, Green tea leaves, Pesticide, Diazinon.

(C) 2018 The Authors. Published by Innovare Academic Sciences Pvt Ltd. This is an open access article under the CC BY license (http://creativecommons. org/licenses/by/4. 0/) DOI: http://dx.doi.org/10.22159/ajpcr.2018.v11i2.22353

\section{INTRODUCTION}

Pesticides and insecticides are used daily and worldwide in agriculture on a massive scale to increase the crop production by controlling the harmful insects and disease vectors. They have conferred benefits to humankind; however, it has some hazards on the biology of humans, especially of the younger age group. Available data estimate that the incidence of pesticide poisonings in developing countries has doubled during the past decade [1]. Among pesticides, organic phosphates are usually used as insecticides and are generally considered to be the most toxic. Diazinon is a commonly used thionophosphorous organophosphate pesticide which is a highly toxic organophosphate compound $[2,3]$. It can be absorbed through various portals such as the digestive system, the skin, and respiratory tract [1]. The primary molecular mechanism of action of the organophosphates is their ability to bind with acetylcholinesterase (AChE) enzyme, thus inhibiting AChE, which results in accumulation of acetylcholine [4-6]. Toxicity of organophosphates also causes adverse effects on many organs such as liver in human and animals, immune system, urinary system, and reproductive system as well. The other effects are hematological and biochemical changes [1,7]. Animal studies show that pre- or postnatal exposure of rodents to diazinon causes considerable changes in a range of biochemical, morphological, and cellular parameters related to nervous system development, leading to persistent defects in behavior and cognition [8]. Another study determined that children had neurological and developmental defects after indoor application of organophosphates [9].

Herbal drugs are known as the oldest form of human health care and the WHO estimates around $80 \%$ of the world uses these drugs because of their negligible side effects [10], and recently, there has been worldwide interest in the role of medicinal plants in complementary medicine. Extracts prepared from medicinal plants and other natural sources contain a variety of molecules with potent biological activities $[11,12]$. Tea is the second most commonly drank liquid in the world after water, and its medicinal properties have been widely explored. Camellia sinensis is a member of the Theaceae family, and different kinds of tea such as black, oolong, and green tea are produced from its leaves. It is being consumed socially and habitually as well by people since early $3000 \mathrm{BC}$. Its pleasing astringent taste and refreshing nature are so deep pervasive that its potential health benefits are often overlooked [13]. The American Medical Association shows that green tea (C. sinensis) can lower cholesterol levels, high blood pressure, and risk of stroke (especially in men). The National Cancer Institute reports its effective use to ward off many types of cancers $[14,15]$. Other than these properties, green tea catechins and polyphenols have many other biological activities such as antifungal, anti-inflammatory, antimutagenic, and antidiabetic and also in treating many liver and stomach disorders [16-19] Tachyspermum ammi L. commonly known as Ajwain or Carum seeds, belong to the family Apiaceae, is one of the highly valued medicinal plants. Its roots are diuretic, and seeds are aphrodisiac in nature. It is prescribed for bowel disorders, colic, diarrhea, and in the treatment of asthma [20]. The main component of its seed oil is thymol [21], a strong germicide, antiseptic, antispasmodic, and fungicide [22]. Therefore, the present study was aimed to investigate the effects of green tea ( $C$. sinensis) leaves and carom seed ( . ammi L.) extracts and their combinatorial use on hematobiochemical variations in mice rendered to sublethal doses of diazinon.

\section{METHODS}

Experimental animals

The experiments were done using male albino mice of MF1 strain, weighing 24-31 g. The mice were obtained from the experimental 
animal house of the institute. The principles and rules of laboratory animal care were followed during all the experiments. The experimental animals were housed in standard polypropylene cages and maintained under controlled laboratory conditions of humidity (65\%), temperature $\left(25 \pm 1^{\circ} \mathrm{C}\right)$, and $12: 12 \mathrm{~h}$ light:dark cycle, with balanced food and water ad libitum. They were initially acclimatized for the study, and the study protocol was approved by the Institutional Animal Ethics Committee as per the requirements of Committee for the Purpose of Control and Supervision on Animals, New Delhi.

\section{Tea leaves and carom seed extraction}

Fresh young leaves of tea were directly collected from some tea plantation farms in Kumaon Hills, Dehradun, Uttarakhand. The leaves were thoroughly washed and dried at room temperature. The fine quality of dried leaves was kept in a dry plastic container until being used for extract preparation. The dried tea leaves $(10 \mathrm{~g})$ were powdered and added to $500 \mathrm{~mL}$ cold water and mixed in an electric mixer for 10 min. Thereafter, the solution of tea leaves was filtered, and the filtrates were evaporated in an oven at $40^{\circ} \mathrm{C}$ to produce dried residues (active principles). With references to the powdered samples, the yield of the tea extract was $17.3 \%$. Furthermore, the extracts were weekly prepared and stored in a refrigerator for subsequent experiments.

\section{Carum seed extracts}

Dried seeds of Carum copticum were procured from medicinal plant nursery in Tehri, Uttarakhand. The collected seeds were rendered free from soil and impurities manually. Plant seeds were then authenticated by Mr. A. Dobriyal, Faculty at Department of Pharmacy, SBSPGIBMS, Dehradun. While the identification completed, each sample was deposited in the SBSPGIBMS School of Pharmacy herbarium with individual voucher number.

The seeds were grounded into a coarse powder (30 g) by electrically grinding mill and were then soaked in fresh distilled water $(300 \mathrm{ml})$. The mixture was then subjected to hydrodistillation for $4 \mathrm{~h}$ using a Clevenger-type apparatus for the extraction of the essential oil [23]. This procedure was done in an appropriate time of day for each sample. The resulting oil was dried over anhydrous sodium sulfate and kept at $4^{\circ} \mathrm{C}$.

Initially, GC/flame ionization detector (FID) analysis of the oils was performed to achieve a desirable analytical condition. Therefore, GC/FID analysis was carried out on a gas chromatograph Agilent technologies model $7890 \mathrm{~A}$ apparatus attached to HP-5 column $(25 \mathrm{~m}, 0.32 \mathrm{~mm}$, $0.52 \mu \mathrm{m}$ film thickness) and connected to FID. Nitrogen was selected as the carrier gas with a flow rate of $1 \mathrm{ml} / \mathrm{min}$ and split ratio was 1:30. The injector temperature was $250^{\circ} \mathrm{C}$, and detector temperature was $280^{\circ} \mathrm{C}$, while column temperature was linearly programed from 60 to $250^{\circ} \mathrm{C}$ (at rate of $5^{\circ} / \mathrm{min}$ ) and then held for $10 \mathrm{~min}$ at $250^{\circ} \mathrm{C}$. Solutions of essential oil samples in dichloromethane $(\sim 1 \%)$ were consecutively injected.

The same analytical method and condition as those mentioned for GC/FID were applied for GC/MS analysis. The process was carried out using Agilent technologies model 7890A gas chromatograph connected to a mass detector (Agilent technologies model 5975C). The gas chromatograph was equipped with a HP-5MS capillary column (phenyl methyl siloxane, $30 \mathrm{~m} \times 0.25 \mathrm{~mm}$ i.d., Agilent technologies). Helium was selected as the carrier gas with the same flow rate as for GC/FID. The mass spectrometer was acquired in EI mode $(70 \mathrm{eV})$ in a mass range of $30-600 \mathrm{~m} / \mathrm{z}$. The interface temperature was $280^{\circ} \mathrm{C}$. Identification of components was based on a comparison of their mass spectra with Willey (nl7) and Adams libraries spectra, as well as with those reported in the literature [24].

\section{Experimental treatments}

A total of 64 mice were randomly divided into eight experimental groups of eight mice each. The experimental groups were treated as follows.
1. Mice of Group 1 were served as controls and intraperitoneally injected with saline solution $(0.9 \% \mathrm{NaCl}), 5$ times weekly, for 7 weeks.

2. Mice of Group 2 were intraperitoneally given diazinon at the level of $6.5 \mathrm{mg} / \mathrm{kg}$ body weight (1/10 of LD 50), 5 times weekly, for 7 weeks.

3. Animals of Group 3 were orally supplemented with tea leaves extract ( $400 \mathrm{mg} / \mathrm{kg}$ body weight) and after $4 \mathrm{~h}$ received diazinon at the same dose given to Group 2, 2 times weekly, for 7 weeks.

4. Mice of Group 4 were orally supplemented with carum seed extract ( $400 \mathrm{mg} / \mathrm{kg}$ body weight) and after $4 \mathrm{~h}$ received diazinon at the same dose given to Group 2, 5 times weekly, for 7 weeks.

5. Animals of Group 5 were orally supplemented with carum seed extract ( $200 \mathrm{mg} / \mathrm{kg}$ body weight) and tea leaves extract ( $200 \mathrm{mg} / \mathrm{kg}$ body weight) and after $4 \mathrm{~h}$ received diazinon at the same dose given to Group 2, 5 times weekly, for 7 weeks.

6. Mice of Group 6 were intraperitoneally received saline solution at the same dose given to Group 1 and were orally supplemented with tea leaves extract at the same dose given to Group 3, 5 times weekly, for 7 weeks.

7. Mice of Group 7 were intraperitoneally received saline solution at the same dose given to Group 1 and were orally supplemented with carum seed extract at the same dose given to Group 4, 5 times weekly, for 7 weeks.

8. Animals of Group 8 were intraperitoneally received saline solution at the same dos e given to Group 1 and were supplemented with tea and carum seed extracts at the same dose given to Group 5, 5 times weekly, for 7 weeks.

\section{Hematobiochemical analyses}

After 7 weeks, mice were anesthetized with diethyl ether. Blood was collected from orbital venous plexus in non-heparinized tubes and centrifuged at $2000 \mathrm{rpm}$ for $20 \mathrm{~min}$, and blood sera were then collected and stored at $4^{\circ} \mathrm{C}$ till the determination time of alanine aminotransferase (ALT), aspartate aminotransferase (AST), gamma-glutamyl transferase (GGT), alkaline phosphatase (ALP), creatine kinase (CK), creatinine, glucose, total protein, triglycerides, and cholesterol using Automated Clinical Chemistry Analysis System, Dimension type RXL Max (Dade Behring Delaware, DE 19714, USA), and automatic analyzer (Reflotron Plus System, Roche, Germany).

\section{Statistical analysis}

Data were expressed as the mean \pm standard deviation and were analyzed by one-way analysis of variance using the Statistical Package for Social Sciences (SPSS for Windows, version 12.0). Multiple comparative analyses were conducted between all experimental groups using Tukey's test. Results were considered statistically significant at $\mathrm{p}<0.05$.

\section{RESULTS}

Male albino mice exposed to sublethal doses of diazinon were treated with green tea leaves, carum seed extracts, and their combination, which showed varied levels of biochemical markers in mice serum. Mice treated with diazinon showed a significant increase in the values of serum ALT $(+180.2 \%)$, AST $(+180.1 \%)$, GGT $(+360.4 \%)$, ALP $(+150.31 \%)$, CK $(+10.2 \%)$, creatinine $(+390.6 \%)$, glucose $(+88.8 \%)$, triglycerides $(+80.4 \%)$, and cholesterol $(+30.1 \%)$ (Group 2) when compared to control mice and other treated groups (Tables 1 and 2). However, the level of total serum protein $(-11.3 \%)$ statistically declined in Group 2 treated mice when compared to control and other treated group mice (Table 2). On comparison with the control mice, the mice treated with tea leaves extract plus diazinon (Group 3), carum seed extract plus diazinon (Group 4), and tea and carum extracts plus diazinon (Group 5) showed a significant increase in values of serum ALT, AST, GGT, ALP, CK, creatinine, glucose, and cholesterol. In addition, some non-significant changes in serum total protein were observed in mice of Groups 3, 4, and 5. The triglycerides level statistically increased in mice treated with tea leaves extract plus diazinon (Group 3), carum 
Table 1: Serum of control and treated mice (with diazinon, diazinon+tea leave extract, Diazinon+carom seed estract, Diazinon+tea leave and carom seed extract, teal leave extract alone, carom seed extract alone, and combination of tea leave and carom seed extracts) showing different concentrations of ALT, AST, GGT, ALP, and CK

\begin{tabular}{|c|c|c|c|c|c|c|}
\hline \multirow[t]{2}{*}{ S. No. } & \multirow[t]{2}{*}{ Treatments } & \multicolumn{5}{|l|}{ Parameters } \\
\hline & & $\operatorname{ALT}(\mathrm{U} / \mathrm{L})$ & $\operatorname{AST}(\mathrm{U} / \mathrm{L})$ & GGT (U/L) & $\operatorname{ALP}(U / L)$ & CK (U/L) \\
\hline 1 & Control & $24.66 \pm 1.82$ & $34.33 \pm 2.11$ & $5.82 \pm 6.21$ & $100.00 \pm 6.32$ & $302.5 \pm 8.12$ \\
\hline 3 & Tea leave extract+Diazinon & $\begin{array}{l}44.52 \pm 1.66^{\mathrm{a}} \\
(+72.2)\end{array}$ & $\begin{array}{l}66.66 \pm 8.21^{\mathrm{a}} \\
(+84.2)\end{array}$ & $\begin{array}{l}12.11+2.22^{\mathrm{a}} \\
(+112.4)\end{array}$ & $\begin{array}{l}152.34 \pm 20.11^{\mathrm{a}} \\
(+50.6)\end{array}$ & $\begin{array}{l}422.20 \pm 52.02^{\mathrm{a}} \\
(+33.3)\end{array}$ \\
\hline 4 & Carom seed extract+Diazinon & $\begin{array}{l}48.32 \pm 2.21 \\
(+72.7)\end{array}$ & $\begin{array}{l}50.22 \pm 12.26^{\mathrm{a}} \\
(+51.2)\end{array}$ & $\begin{array}{l}14.22 \pm 3.22^{\mathrm{a}} \\
(161.5)\end{array}$ & $\begin{array}{l}158.26 \pm 28.20^{\mathrm{a}} \\
(+54.7)\end{array}$ & $\begin{array}{l}452.67 \pm 60.2^{\mathrm{a}} \\
(+46.0)\end{array}$ \\
\hline 5 & $\begin{array}{l}\text { Tea leave extract and carom seed } \\
\text { extract+Diazinon }\end{array}$ & $\begin{array}{l}35.50 \pm 4.01^{\mathrm{a}} \\
(+34.6)\end{array}$ & $\begin{array}{l}44.60 \pm 8.22^{\mathrm{a}} \\
(+24.1)\end{array}$ & $\begin{array}{l}6.00 \pm 2.21^{\mathrm{a}} \\
(+42.20)\end{array}$ & $\begin{array}{l}141.61 \pm 22.71^{\mathrm{a}} \\
(+41.2)\end{array}$ & $\begin{array}{l}420.22 \pm 80.60^{\mathrm{a}} \\
(+32.7)\end{array}$ \\
\hline 6 & Tea leave extract & $\begin{array}{l}26.5 \pm 2.72 \\
(-4.2)\end{array}$ & $\begin{array}{l}36.71 \pm 3.22 \\
(+3.3)\end{array}$ & $\begin{array}{l}5.24 \pm 2.26 \\
(-4.6)\end{array}$ & $\begin{array}{l}104.6 \pm 11.12 \\
(+1.20)\end{array}$ & $\begin{array}{l}310.31 \pm 22.15 \\
(+1.6)\end{array}$ \\
\hline 7 & Carom seed extract & $\begin{array}{l}28.24 \pm 2.51 \\
(-2.2)\end{array}$ & $\begin{array}{l}35.41 \pm 2.11 \\
(+1.2)\end{array}$ & $\begin{array}{l}5.31 \pm 0.82 \\
(-3.1)\end{array}$ & $\begin{array}{l}98.40 \pm 8.2 \\
(-4.0)\end{array}$ & $\begin{array}{l}308.24 \pm 20.11 \\
(+2.0)\end{array}$ \\
\hline 8 & Tea leave extract+Carom seed extract & $\begin{array}{l}26.33 \pm 2.21 \\
(-5.2)\end{array}$ & $\begin{array}{l}35.42 \pm 3.26 \\
(+0.22)\end{array}$ & $\begin{array}{l}5.30 \pm 0.56 \\
(-4.2)\end{array}$ & $\begin{array}{l}100 \pm 8.4 \\
(-0.3)\end{array}$ & $\begin{array}{l}298.31 \pm 16.2 \\
(-2.2)\end{array}$ \\
\hline
\end{tabular}

ALT: Alanine aminotransferase, AST: Aspartate aminotransferase, GGT: Gamma-glutamyl transferase, ALP: Alkaline phosphatase, CK: Creatine kinase. Percentage

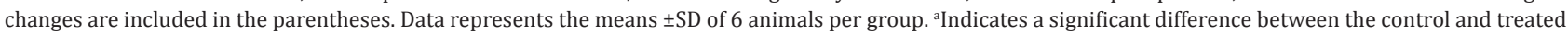
groups. ${ }^{b}$ Indicates a significant difference between mice exposed to diazinon and tea leaves extract + diazinon, carom seed extract plus diazinon, tea and carom extracts plus diazinon, tea leave extract, carom seed extract and tea and carom extracts treated mice

Table 2: Serum of control and treated mice (with diazinon, diazinon+tea leave extract, diazinon+carom seed estract, diazinon+tea leave and carom seed extract, teal leave extract alone, carom seed extract alonem and combination of tea leave and carom seed extracts) showing different concentrations of creatinine, glucose, total protein, triglyceridesm and cholesterol

\begin{tabular}{|c|c|c|c|c|c|c|}
\hline \multirow[t]{2}{*}{ S. No. } & \multirow[t]{2}{*}{ Treatments } & \multicolumn{5}{|l|}{ Parameters } \\
\hline & & $\begin{array}{l}\text { Creatinine } \\
(\mathrm{mg} / \mathrm{dl})\end{array}$ & $\begin{array}{l}\text { Glucose } \\
\text { (mg/dl) }\end{array}$ & $\begin{array}{l}\text { Total protein } \\
\text { (g/dl) }\end{array}$ & $\begin{array}{l}\text { Triglycerides } \\
\text { (mg/dl) }\end{array}$ & $\begin{array}{l}\text { Cholesterol } \\
\text { (mg/dl) }\end{array}$ \\
\hline 1 & Control & $0.57 \pm 0.14$ & $80.12 \pm 9.3$ & $5.98 \pm 0.43$ & $80.24 \pm 4.65$ & $91.80 \pm 5.22$ \\
\hline 2 & Diazinon & $\begin{array}{l}2.93 \pm 1.44^{\mathrm{ab}} \\
(+390.60)\end{array}$ & $\begin{array}{l}172.17 \pm 46.44^{\mathrm{a}} \\
(+88.8)\end{array}$ & $\begin{array}{l}4.63 \pm 0.26^{\mathrm{ab}} \\
(-11.3)\end{array}$ & $\begin{array}{l}162.20 \pm 28.51^{\mathrm{ab}} \\
(+80.4)\end{array}$ & $\begin{array}{l}221.81 \pm 30.1^{\mathrm{ab}} \\
(30.1)\end{array}$ \\
\hline 3 & Tea leave extract+Diazinon & $\begin{array}{l}1.58 \pm 0.90^{\mathrm{ab}} \\
(+150.0)\end{array}$ & $\begin{array}{l}130.33 \pm 20.30^{\mathrm{a}} \\
(+52.0)\end{array}$ & $\begin{array}{l}5.11 \pm 0.30 \\
(-6.0)\end{array}$ & $\begin{array}{l}108.67 \pm 14.6^{\mathrm{a}} \\
(+22.0)\end{array}$ & $\begin{array}{l}164.11 \pm 35.9^{a} \\
(+70.1)\end{array}$ \\
\hline 4 & Carom seed extract+Diazinon & $\begin{array}{l}1.48 \pm 0.33^{\mathrm{a}} \\
(+140.9)\end{array}$ & $\begin{array}{l}122.50 \pm 11.2^{\mathrm{a}} \\
(+42.22)\end{array}$ & $\begin{array}{l}5.22 \pm 0.22 \\
(-2.7)\end{array}$ & $\begin{array}{l}96.60 \pm 16.8^{\mathrm{a}} \\
(16.2)\end{array}$ & $\begin{array}{l}140.11 \pm 22.37^{\mathrm{a}} \\
(+50.0)\end{array}$ \\
\hline 5 & $\begin{array}{l}\text { Tea leave extract and carom seed } \\
\text { extract+Diazinon }\end{array}$ & $\begin{array}{l}1.44 \pm 0.48^{\mathrm{a}} \\
(+134.8)\end{array}$ & $\begin{array}{l}158.67 \pm 24.5^{\mathrm{a}} \\
(+80.2)\end{array}$ & $\begin{array}{l}5.33 \pm 0.29 \\
(-4.4)\end{array}$ & $\begin{array}{l}80.00 \pm 5.9^{a} \\
(-1.46)\end{array}$ & $\begin{array}{l}126.66 \pm 8.46^{a} \\
(+35.6)\end{array}$ \\
\hline 6 & Tea leave extract & $\begin{array}{l}0.68 \pm 0.12 \\
(+10.1)\end{array}$ & $\begin{array}{l}94.11 \pm 22.23 \\
(+5.66)\end{array}$ & $\begin{array}{l}5.56 \pm 0.21 \\
(-0.81)\end{array}$ & $\begin{array}{l}81.00 \pm 4.46 \\
(-4.2)\end{array}$ & $\begin{array}{l}94.22 \pm 6.22 \\
(-0.98)\end{array}$ \\
\hline 7 & Carom seed extract & $\begin{array}{l}0.56 \pm 0.18 \\
(-14.6)\end{array}$ & $\begin{array}{l}74.93 \pm 6.99 \\
(-14.2)\end{array}$ & $\begin{array}{l}5.55 \pm 0.32 \\
(-1.6)\end{array}$ & $\begin{array}{l}76.81 \pm 4.1 \\
(-4.4)\end{array}$ & $\begin{array}{l}80.46 \pm 6.2^{a} \\
(12.66)\end{array}$ \\
\hline
\end{tabular}

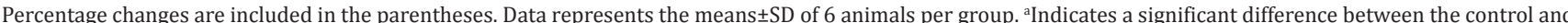
treated groups. ${ }^{\mathrm{b}}$ Indicates a significant difference between mice exposed to diazinon and tea leaves extract+diazinon, carom seed extract plus diazinon, tea and carom extracts plus diazinon, tea leave extract, carom seed extract and tea and carom extracts treated mice

seed extract plus diazinon (Group 4), while the levels remain unchanged in mice supplemented with tea leaves and carum seed extracts plus diazinon (Group 5).

In addition, no significant statistical difference was perceived in the values of all hematobiochemical parameters in mice treated with tea leave extract (Group 6), carum seed extract (Group 7), and tea leave and carum seed extracts (Group 8) except the value of serum cholesterol in mice treated with carum seed extract (Group 8) which decreased as compared to the control group.

Furthermore, Tables 1 and 2 demonstrate that the high percentage changes of the studied hematobiochemical parameters in mice exposed to diazinon were reduced by treatments of tea leave extracts (Group 3), carum seed extracts (Group 4), and by a combination of both (Group 5).
Together, the above results indicate that the noxious effect of diazinon was much decreased and attenuated with the combinatorial effect of green tea leave and carum seed extracts.

\section{DISCUSSION}

To the best of our knowledge, it is the first animal study of its kind which decifers the combinatorial effect of green tea and carom seed extracts on the toxigenicity of diazinon. The values of routine biochemical markers such as serum ALT, AST, GGT, ALP, CK, creatinine, glucose, triglycerides, and cholesterol were significantly higher, while low serum protein was observed with mice which were exposed only to diazinon. These results were in concordance with observations of the previous studies which also showed severe alterations in physiological and biochemical parameters in experimental animals [25-30]. The increase in the levels of ALP, ALT, AST, and GGT seen 
here indicated liver dysfunction, and these markers have been in use for biochemically monitoring chemical-induced tissue damage [31]. In addition, reports also confirm the release of these biomarkers in bloodstream when the hepatic parenchymal cells are exposed to toxic pesticides like diazinon [26,28-30]. CK is the first cardiac enzyme to be released in the blood when there is a cardiac arrest [26]. Thus, the increase in the value of CK in our study after diazinon exposure indicates that it might be some kind of damage or necrosis in cardiac muscle tissue. Moreover, also knowing that it is short lived in blood, it becomes more imperative to study this enzyme in pesticide-induced toxicity. These observations were supported by Attar et al. in different studies which also showed cardiotoxicity due to diazinon exposure in experimental animals [26,27,31]. In addition, reports also show that serum creatinine levels also affect renal function, as there is a decrease in the amount of creatinine in malfunctioned kidneys, thus increasing blood creatinine levels. This indicated disturbances in glomerular filtration rates [32]. The results also indicate an increase in values of serum glucose triglycerides and cholesterol while serum protein levels declined by exposure to diazinon. This observation points toward a direct effect of diazinon toxicity on carbohydrate, lipid, and protein metabolisms. Increase in serum glucose levels due to diazinon intoxication is indicative of hyperglycemic mice that might be a result of an increase in enzyme activities involved in the process of gluconeogenesis. Thus, it will lead to glucose molecules generation from non-carbohydrate sources in conjunction with the obstruction of liver glycogenolysis. Agbor et al. [33] reported that accumulation of blood triglycerides may be a result of imbalance between the rate of synthesis and rate of release of triglycerides by the parenchymal cells into the systemic circulation. The present study also indicated a boost of serum cholesterol and hypercholesterolemia in mice exposed to diazinon. This increase indicates the inhibitory action of pesticide on cytochrome P450 enzymes. Furthermore, increased cholesterol concentration indicates liver disorders and cholestasis [19,34,35]. Our findings are in concordance with many previous reports which have shown the cause of hypoproteinemia could be due to a significant decrease in protein synthesis or might be because of any renal dysfunction, liver injury, or elimination of proteins in the urine $[36,37]$. Tissue degeneration is a free radical-mediated process that involves lipid peroxides and lipid peroxidation of polyunsaturated fatty acids of mammalian tissue [38]. Therefore, lipid peroxidation is suggested to be one of the important molecular mechanisms involved in pesticide-induced cytotoxicity [39]. C. sinensis, the traditional green tea is proven to have a high content of flavonoids which are phenolic compounds of plants and have been attributed for several functions including many health benefits. These flavonoids are potent antioxidants, and metal chelators which protect cells from reactive oxygen species or free oxygen radicals are a few among many other good studies which have shown the protective effect of green tea on pesticides and organophosphorus compounds [40-47]. In addition, this study also explored the use of carum seed extract which has also been studied in the prevention of decrease in antioxidant levels and having an ameliorative effect on hematological, biochemical, and histopathological alterations. The main ingredient, i.e. isothymol and other active ingredients of crude extract of carum seeds have shown to possess antiaggregatory effects [48], anthelmintic [49], antihyperlipidemic [50], anti-filarial [51], insecticidal [52], kidney stone inhibitory [53], molluscicidal [20], mosquito repellent [54], and nematicidal activities [49].

\section{CONCLUSION}

This study is an attempt toward showing the promising role of extracts of green tea and carum seeds in preventing hepatotoxicity, cardiotoxicity, nephrotoxicity, and metabolic disorders induced due to diazinon. Furthermore, there is a need of biochemical, histopathological, and physiological investigations using different dosages of these crude extracts to prove the plausible role of these extracts in preventing diazinon toxicity. In addition, the combinatorial effect of these extracts might also be explored to study their effect on other toxicants and pathogenic moieties.

\section{AUTHORS CONTRIBUTIONS:}

Manju O Pai (MOP) and Anil k Gupta(AKG) performed the experiments. Venkatesh S Pai (VSP) and Manju O Pai (MOP) edited and wrote the manuscript.

\section{CONFLICTS OF INTEREST}

There are no conflicts of interests.

\section{REFERENCES}

1. Shah MD, Iqbal M. Diazinon-induced oxidative stress and renal dysfunction in rats. Food Chem Toxicol 2010;48:3345-53.

2. Colović M, Krstić D, Petrović S, Leskovac A, Joksić G, Savić J, et al. Toxic effects of diazinon and its photo degradation products. Toxicol Lett 2010;193:9-18.

3. Morgan MK, Sheldon LS, Jones PA, Croghan CW, Chuang JC, Wilson NK, et al. The reliability of using urinary biomarkers to estimate children's exposures to chlorpyrifos and diazinon. J Expo Sci Environ Epidemiol 2011;21:280-90

4. Baireddy P, Liu J, Hinsdale M, Pope C. Comparative effects of chlorpyrifos in wild type and cannabinoid cb1 receptor knockout mice. Toxicol Appl Pharmacol 2011;256:324-9.

5. Balali-Mood M, Shirazi FH. Recent advances in treatment of acute organophosphorous nerve agents poisoning. Iran $\mathrm{J}$ Pharm Res 2006;5:79-87.

6. Fazekas B, Ivanics E, Hajtos I, Glavits R. Diazinon toxicosis in geese. Open Toxicol 2008;1:5-8.

7. Flaskos J, Nikolaidis E, Harris W, Sachana M, Hargreaves AJ. Effects of sub-lethal neurite outgrowth inhibitory concentrations of chlorpyrifos oxon on cytoskeletal proteins and acetyl cholinesterase in differentiating N2a cells. Toxicol Appl Pharmacol 2011;256:330-6.

8. Yen J, Donerly S, Levin ED, Linney EA. Differential acetyl cholinesterase inhibition of chlorpyrifos, diazinon and parathion in larval zebrafish. Neurotoxicol Teratol 2011;33:735-41.

9. Karakoca K, Ozusaglam MA, Cakmak YS, Erkul SK. Antioxidative, antimicrobial and cytotoxic properties of Isatis floribunda Boiss. Ex Bornm. extracts. EXCLI J 2013;12:150-67.

10. Watanabe CM, Wolffram S, Ader P, Rimbach G, Packer L, Maguire JJ, et al. The in vivo neuromodulatory effects of the herbal medicine Ginkgo biloba. Proc Natl Acad Sci U S A 2001;98:6577-80.

11. Sharangi AB. Medicinal and therapeutic potentialities of tea (Camellia sinensis L.)-a review. Food Res Int 2009;42:529-35

12. Kumar A, Pai MO, Rai N. In-vitro hepatoprotective activity of Albizia lebbeck, Cassia occidentalis and Swertia chirata on HEPG2 cells. Asian J Pharm Clin Res 2016;9:276-80.

13. Al-Attar AM, Zeid IM. Effect of tea (Camellia sinensis) and Olive (Olea europaea L.) leaves extracts on male mice exposed to diazinon. BioMed Res Int 2013;2013:1-6.

14. Kimberly AG, Lambert JD. Laboratory, epidemiological, and human intervention studies show that tea (Camellia sinensis) may be useful in the prevention of obesity. J Nutr 2010;140:446-53.

15. Wang ZY, Cheng SJ, Zhou ZC, Athar M, Khan WA, Bickers DR, et al. Antimutagenic activity of green tea polyphenols. Mutat Res 1989;223:273-85.

16. Ho CT, Chen Q, Shi H, Zhang KQ, Rosen RT. Antioxidative effect of polyphenol extract prepared from various Chinese teas. Prev Med 1992;21:520-5.

17. Chisaka T, Matsuda H, Kubomura Y, Mochizuki M, Yamahara J, Fujimura $H$. The effect of crude drugs on experimental hypercholesteremia: Mode of action of epigallocatechin gallate in tea leaves. Chem Pharm Bull 1998;36:227-33.

18. Al-Attar AM, Zari TA. Influences of crude extract of tea leaves, Camellia sinensis, on streptozotocin diabetic male albino mice. Saudi J Biol Sci 2010;17:295-301.

19. Bairwa R, Sodha RS, Rajawat BS. Trachyspermum ammi. Pharmacogn Rev 2012;6:56-60.

20. Singh I, Singh VP. Antifungal properties of aqueous and organic extracts of seed plants against Aspergillus flavus and A. niger. Phytomorphology 2000;20:151-7.

21. Sivropoulou A, Papanikolaou E, Nilolaou C, Kokkini S, Lanaras T, Arsenakis M. Antimicrobial and cytotoxic activities of origanum essential oils. J Agric Food Chem 1999;44:1202-5.

22. Anonymous. British Pharmacopoeia. London: HMS; 1988. p. 137-8.

23. Adams RP. Identification of Essential Oil Components by Gas Chromatography/Mass Spectroscopy. Carol Stream, IL: Allured 
Publishing Co.; 1995.

24. Zarshenas MH, Samani SM, Petramfar P, Moein M. Analysis of the essential oil components from different Carum copticum L. samples from Iran. Pharmacognosy Res 2014;6:62-6.

25. Ibrahim NA, El-Gamal BA. Effect of diazinon, an organophosphate insecticide, on plasma lipid constituents in experimental animals. J Biochem Mol Biol 2003;36:499-504.

26. Al-Attar AM. The ameliorative role of $\beta$-carotene pretreatment on diazinon-induced enzymological and histopathological changes in wistar male rats. Glob J Pharm 2009;3:171-7.

27. Al-Attar AM, Al-Taisan WA. Preventive effects of black seed (Nigella sativa) extract on sprague dawley rats exposed to diazinon. Aust J Basic Appl Sci 2010;4:957-68.

28. Zari TA, Al-Attar AM. Therapeutic effects of olive leaves extract on rats treated with a sublethal concentration of carbendazim. Eur Rev Med Pharmacol Sci 2011;15:413-26.

29. Al-Attar AM. Physiological and histopathological investigations on the effects of alpha-lipoic acid in rats exposed to Malathion. J Biomed Biotechnol 2010;2010:203503.

30. Mossa AT, Refaie AA, Ramadan A. Effect of exposure to mixture of four organophosphate insecticides at no observe adverse effect level dose on rat liver: The protective role of vitamin C. Res J Environ Toxicol 2011;5:323-35.

31. Chatterjea MN, Shinde R. Text Book of Medical Biochemistry. $6^{\text {th }}$ ed. New-Delhi, India: Jaypee Broth; 2005.

32. Jalili S, Farshid AA, Heydari R, Ilkhanipour M, Salehi S. Histopathological observations on protective effects of vitamin $\mathrm{E}$ on endosulfan induced cardiotoxicity in rats. Pak J Biol Sci 2007; 10:1922-5

33. Hayes AW. Principles and Methods of Toxicology. $3^{\text {rd }}$ ed. New York, NY, USA: Raven Press; 1994

34. Agbor GA, Oben JE, Nkegoum B, Takla JP, Ngogang JY. Hepatoprotective activity of Hibiscus cannabinus (Linn.) against carbon tetrachloride and paracetamol induced liver damage in rats. Pak J Biol Sci 2005;8:1397-401.

35. Shivanandappa T, Krishnakumari MK. Histochemical and biochemical changes in rats fed dietary benzene hexachloride. Indian J Exp Biol 1981;19:1163-8.

36. Zarn JA, Br"uschweiler BJ, Schlatter JR. Azole fungicides affect mammalian steroidogenesis by in hibitingsterol $14 \alpha$-demethylase and aromatase. Environ Health Perspect 2003;111:255-61.

37. Pfeifer KF, Weber LJ. The effect of carbon tetrachloride on the total plasma protein concentration of rainbow trout, Salmo gairdneri. Comp Biochem Physiol 1979;64:37-42.

38. Muthuviveganandavel V, Muthuraman P, Muthu S, Srikumar K. Biochemical evaluation of low dose methyl 2-benzimidazole carbamate fungicide on male albino rats. Int J Drug Deliv 2010;2:352-6.

39. Debnath D, Mandal TK. Study of quinalphos (an environmental oestrogenic insecticide) formulation (Ekalux 25 E.C.)-induced damage of the testicular tissues and antioxidant defence systems in sprague- dawley albino rats. J Appl Toxicol 2000;20:197-204.

40. Banerjee BD, Seth V, Bhattacharya A, Pasha ST, Chakraborty AK. Biochemical effects of some pesticides on lipid peroxidation and freeradical scavengers. Toxicol Lett 1999;107:33-47.

41. Rietveld A, Wiseman S. Antioxidant effects of tea: Evidence from human clinical trials. J Nutr 2003;133:3285S-92S.

42. El-Kott AF, Bin-Meferij MM. Influence of green tea on haematological and lung histological disorders induced by malathion in rats. Res $\mathrm{J}$ Environ Toxicol 2008;2:85-91.

43. Korany NS, Ezzat BA. Prophylactic effect of green tea and Nigella sativa extracts against fenitrothion-induced toxicity in rat parotid gland. Arch Oral Biol 2011;56:1339-46

44. Srivastava KC. Extract of a spice - omum (Trachyspermum ammi)shows antiaggregatory effects and alters arachidonic acid metabolism in human platelets. Prostaglandins Leukot Essent Fatty Acids 1988;33:1-6.

45. Heikal TM, Mossa AT, Rasoul MA, Marie GIK. The ameliorating effect of green tea extract against cyromazine and chlorphylifos induced liver toxicity in male rats. Asian J Pharm Clin Res 2013;6:48-55.

46. Rathod S, Manita W. Antibacterial activity of green tea extract in combination with cefotaxime on diarrhea causing ESBL producing E.coli. Int J Pharm Pharm Sci 2015;7:258-62.

47. Hegazy R, Moustafa R, El-Melingy R. The therapeutic and neuroprotective effects of green tea in a rat model of terlipressin induced chronic hyponatremia. Int J Pharm Pharm Sci 2016;8:253-9.

48. Lateef M, Iqbal Z, Akhtar MS, Jabbar A, Khan MN, Gilani AH, et al. Preliminary screening of Trachyspermum ammi (L.) seed for anthelmintic activity in sheep. Trop Anim Health Prod 2006;38:491-6.

49. Javed I, Iqbal Z, Rahman Z, Khan FH, Muhammad F, Aslam B, et al. Comparative antihyperlipidaemic efficacy of Trachyspermum ammi extracts in albino rabbits. Pak Vet J 2006;26:23-9.

50. Mathew N, Bhattacharya SM, Perumal V, Muthuswamy K. Antifilarial lead molecules isolated from Trachyspermum ammi. Molecules 2008;13:2156-68.

51. Park IK, Kim J, Lee SG, Shin SC. Nematicidal activity of plant essential oils and components from ajowan (Trachyspermum ammi), allspice (Pimenta dioica) and Litsea (Litsea cubeba) essential oils against pine wood nematode (Bursaphelenchus xylophilus). J Nematol 2007:39:275-9

52. Kaur T, Bijarnia RK, Singla SK, Tandon C. In vivo efficacy of Trachyspermum ammi anticalcifying protein in urolithiatic rat model. J Ethnopharmacol 2009;126:459-62.

53. Singh G, Maurya S, Catalan C, De Lampasona MP. Chemical constituents, antifungal and antioxidative effects of ajwain essential oil and its acetone extract. J Agric Food Chem 2004;52:3292-6.

54. Pandey SK, Upadhyay S, Tripathi AK. Insecticidal and repellent activities of thymol from the essential oil of Trachyspermum ammi (Linn) sprague seeds against anopheles stephensi. Parasitol Res 2009;105:507-12. 